\title{
EVA KŘİŽovÁ
}

\section{SOCIOLOGIE NA POLI MEDICÍNY A ZDRAVOTNICTVÍ - CIZINEC NEBO VETŘELEC?}

Sociologie medicíny a zdravotnictví je jednou z nejmladších sociologických subdisciplín, která se přes své poměrně pozdní datum vzniku rozvíjela v poválečných desetiletích natolik dynamicky, že se stala v USA jednou z nejaktivnějších a nejpočetnějších sekcí Americké sociologické společnosti. Vznik sociologie medicíny jako samostatného podoboru je spjat $s$ obdobím po 2 . světové válce a americkým univerzitním prostředím. $V$ průběhu 50 . let začaly díky podpoře státu a mnoha neziskových organizací vznikat samostatné katedry sociologie na lékařských fakultách a jiných institucích zdravotnického vzdělávání. Na základě tohoto impulzu se institucionalizovala sociologie medicíny rovněž v západní Evropě (především Německu, Francii a Velké Británii), a později v některých středoevropských a východoevropských zemích se silnou sociologickou obcí nebo tradicí sociologického myšlení (např. Polsko, Československo). To však neznamená, že by se sociologické přistupy v oblasti zdravotnictví nevyuživaly již dřive. Právě pro evropské myšlení je přiznačná silná sociální vnímavost, jež našla své uplatnění rovněž v oblasti medicíny. Také velké osobnosti zakladatelského období sociologie 19. století věnovaly pozornost jevům, jež zasahovaly do oblasti lidského zdraví a nemoci. Nicméně, i když i mezi autory zakladatelského sociologického období najdeme práce s tématy blízkými zdravotnictví (jako je např. Durkheimova Sebevražda a Le Playova Rodina), formálně se pozornosti sociálním aspektům moderního lékařství v průběhu 19. a první polovině 20 . století dostávalo spíše pod hlavičkou jiných vědních disciplín, nap̌r. sociálního lékařství a sociální hygieny, později veřejného zdravotnictví. Konkurence různých oborů a jejich snaha monopolizovat si zkoumání určitých otázek je však bohužel charakteristická i pro současné období, kdy se na poli zdravotnictví etablovaly dalši samostatné obory jako zdravotnická politika, zdravotnická ekonomika, lékařská etika a další.

Termín sociologie medicíny (medical sociology) užil poprvé ve svém článku v roce 1894 Charles Mc Intire [Matcha 2000: 8], který ji však chápal poměrně úzce jako vědu zabývající se sociálními aspekty lékařské profese a studující pravidla, za nichž je výkon lékařské profese provozován a jimiž je regulován. V r. 1902 nazvala Elizabeth Blackwellová, první lékařka ve Spojených státech, titulem Essays in Medical 
Sociology soubor svých článků na téma sociální práce a veřejné zdravotnictví [Blackwell 1902]. Po celé období 20.-30. let byla však sociologie medicíny synonymem pro sociální lékařství. I když intelektuálně byly základy pro sociologii medicíny a zdravotnictví položeny již dřive, $\mathrm{k}$ její formalizaci došlo až po 2 . světové válce jednak $v$ souvislosti s mohutným vědeckovýzkumným rozvojem medicíny, jednak pod vlivem sociálních, politických a kulturních proměn. V r. 1955 vznikla v rámci Americké sociologické společnosti neformální skupina pro sociologii medicíny a v r. 1959 se konstituovala v první samostatnou sekci transformované sociologické společnosti. Od r. 1965 začala Americká sociologická společnost vydávat specializovaný odborný časopis The Journal of Health and Social Behavior.

Podle Rudermana [Ruderman 1981: 927] se sociologie medicíny a zdravotnictví (v angličtině medical sociology) zabývá „studiem systému zdravotní péče jako společenské instituce a otázkami zdraví a nemoci a jejich vztahu k sociálním faktorům“. Americká sociologická společnost ji definuje jako „subdisciplínu, která aplikuje sociologické perspektivy, pojmy, teorie a metodologické př́stupy na zkoumání jevů spojených s lidským zdravím a nemocemi. Jako sociologická specializace zahrnuje množství znalostí, jež uvádějí zdraví a nemoc do sociálního, kulturního a behaviorálního kontextu“ [Matcha 2000: 6]. Schematicky je možné uvažovat o třech tematických rovinách:

- nemoc a zdraví na mikrosociální úrovni se zvláštní pozorností věnovanou psychosociálním okolnostem vzniku nemoci jedince, jeho chování v nemoci a vztahu mezi lékařem a pacientem,

- nemoc a zdraví na kolektivní úrovni s dominantní otázkou, které sociální faktory a indikátory sociální příslušnosti mají vliv na rozdíly v životním způsobu, zdravotním stavu a spotřebě zdravotní péče,

- instituce zdravotnictví s hlavním zájmem o hodnoty a kulturu medicíny a zdravotnictví jako součást společenského systému.

Pro etablování sociologie medicíny a zdravotnictví byly z historického hlediska důležité následující okolnosti. Klíčovým byl dodnes nepřekonaný teoretický příspěvek Talcotta Parsonse [Parsons 1951], který analyzoval moderní zdravotnictví jako součást společenského celku, definoval roli lékaře a pacienta a vymezil sociologické pojetí nemoci. Podle Parsonse je nemoc formou sociální deviace. Nemoc ve svých důsledcích ohrožuje fungování a trvání společnosti a každá společnost má funkcionální zájem na kontrole nemoci a umírání. „Př́iliš nízká úroveň všeobecného zdraví a příliš vysoká nemocnost jsou pro společnost dysfunkční, a to především proto, že nemoc znemožňuje plnění sociálních závazků a rolí ... Nemoc je poruchou normálního fungování jak na biologické úrovni, tak v rovině sociálního přizpůsobení, je tedy částečně biologicky a částečně sociálně definována. Participace v sociálním systému je vždy potenciálně relevantní pro stav dané nemoci, pro její etiologii a pro podmínky úspěšné léčby stejně jako pro mnohé další okolnosti“ [Parsons 1951: 430-431]. Moderní medicína je mechanismem sociálního systému, jehož funkcí je zvládat nemoci lidí jako členů společenských skupin. Lékař se stává činitelem sociální kontroly a jeho posuzování zdravotního stavu nemá důsledky jen pro daného jedince, nýbrž ovlivňuje každou skupinu, jejímž je nemocný členem. 
Role pacienta je definována dvěma povinnostmi a dvěma výhodami:

1. Nemocný je na základě svého stavu legitimně vyčleněn ze svých běžných sociálních závazků a povinností. Podle konkrétní situace, v níž se nachází, může tato neutrálně formulovaná skutečnost být bud' pro nemoc stimulující, nebo naopak může vést $\mathrm{k}$ popření nemoci a ,úniku do zdraví“.

2. Nemoc není chápána jako akt vủle a nemocnému není přičítána odpovědnost za to, že onemocněl - to odlišuje tuto podobu sociální deviace od jiných. Nemocný potřebuje pomoc druhých, nebot uzdravit se je mimo jeho kompetence. Jeho situace se vyznačuje potřebností a odkázaností na druhé. Díky emocionálním důsledkủm, jež obavy o zdraví či bolest nebo zdravotní porucha přinášejí, je podle Parsonse nemocný oprávněn $\mathrm{k}$ tomu získat pomoc druhých. Ve vztahu ke svým potřebám je však nekompetentní, neumí je posoudit, není pro to odborně vybaven.

3. Nemocný nemá setrvávat ve stavu nemoci déle, než je nutné, jeho motivace má být orientována na znovuobnovení zdraví. Nadbytečné setrvávání v nemoci má sám chápat jako nežádoucí. Parsons si uvědomuje, že motivace k nemoci nemusí být úmyslná a často se opírá o podvědomá prání.

4. Za tím účelem má nemocný vyhledat odbornou pomoc a spolupracovat s lékaři a dalšími profesionálními zdravotnickými pracovníky. Očekává se, že bude ve vlastním zájmu respektovat doporučení odborníků a dodržovat léčebný režim.

Komplementární rolí nemocného je role lékaře, již Parsons charakterizoval požadavky univerzalismu, funkční specifičnosti, afektivní neutrality a kolektivní orientace. $\mathrm{V}$ duchu těchto hodnot se od lékařů požaduje, aby své znalosti a dovednosti poskytli všem, kdo je potřebují, a nerozlišovali mezi pacienty podle sympatií a sociálního postavení. Lékaři nemají vnášet do klinického rozhodování v rámci své odbornosti posuzování chování a přesvědčení nemocného. Společnost také předpokládá, že primárním motivem pro výkon lékařské profese není ekonomický zisk, ale ohled na zájmy nemocného. Prospěch pacienta stojí podle společenského očekávání nad vlastními finančními potřebami lékaře. Neznamená to, že lékař musí zcela zapomenout na to, za jakých podmínek vykonává svou profesi. V situaci konkrétního konfliktu je však etickým imperativem upřednostnit zájmy nemocného a vlastní potřeby řešit ve formě společenského vyjednávání prostřednictvím lékařské reprezentace a stavu.

Parsons tak jako jeden z prvních poukázal na to, že ne každý nemocný je pacient a ne každý pacient je nemocný a hovořil o „,sekundárním zisku z nemoci“ $v$ důsledku motivace stát se či zůstat nemocným. Uvědomoval si také změnu sociálního postavení nemocného charakterizovanou ztrátou odpovědnosti, a tím i osobní svobody. Stejně tak upozornil na konstantu lékařské profese ve všech historických a kulturních kontextech, jíž je altruismus. Kritické výhrady vůči Parsonsově koncepci sociální role nemocného $\mathrm{z}$ pozdější doby připomínají, že $\mathrm{v}$ důsledku měnícího se obrazu nemocnosti a pandemii civilizačních chorob bezprostředně souvisejících se životním způsobem je nutné hledat adekvátní míru osobni odpovědnosti za vlastní zdraví. Mnozí chronicky nemocní lidé jsou odborníky na svou nemoc v kontextu svého prrirozeného světa, mají s nemocí dlouhodobou každodenní zkušenost na vlastním těle a ve vlastním proživání. Proto se pohled nemocného stává stále více důležitým při posuzování jeho potřeb a nemocný se stává stále aktivnějším účastníkem vztahu. Dále je také zpo- 
chybněna povinnost nemocného spolupracovat se systémem profesionálních zdravotnických služeb, nebot se opomíji prostor pro samoléčbu a laickou nekonvenční/alternativní péči. Parsons sám se ale ve své kapitole vyjádřil $\mathrm{k}$ tomu, že v medicíně je stále velký prostor pro magické procesy, a to nejen v medicíně tradičních společností, nýbrž i v západní civilizaci vyznávající kult vědy. Vnímání otázek zdraví a nemoci z laické perspektivy se tedy $\mathrm{v}$ žádném př́padě neomezuje pouze na vědeckou rovinu.

Dalším příspěvkem k osamostatnění sociologie medicíny byl článek Roberta Strause z r. 1957 [Straus 1957: 203], který se na základě empirického šetření mezi sociologickými pracovišti pokusil o vnitřní strukturaci sociologie medicíny podle typu studovaných problémů a na základě způsobu jejich nahlížení. Sociologie medicíny či v medicíně ${ }^{1}$ (sociology in medicine) se zabývá zkoumáním sociálních aspektů zdraví a nemoci s primárním účelem posloužit lepšímu porozumění mechanismům ochrany a udržení zdraví, nástupu a výskytu onemocnění, léčby a rehabilitace. Sociologie tak spolupracuje při realizaci lékařských a zdravotnických výzkumů a přizpůsobuje své dovednosti, spíše než znalosti, praktické aplikaci. Účelem takového výzkumu není zasvěcená sociologická analýza, nýbrž hlubší posouzení zdravotnické problematiky s ohledem na sociální souvislosti sledovaných fenoménů. Sociologie zde ztrácí svou autonomii a nabízí k využití především svůj metodologický potenciál.

Naproti tomu sociologie medicínské praxe a zdravotnictví jako instituce (sociology of medicine) si udržuje svou sociologickou kvalifikaci nejen v oblasti empirického výzkumu, ale i v oblasti interpretace zjištěných skutečností a teoretických ambicí. Studuje tak medicínu a zdravotnictví jako součást sociálního světa. Zvlášt se zaměruje na relevantní hodnoty, normy a role, analyzuje sociální struktury, rituály, skupinové zájmy a mechanismy jejich prosazování. Již z tohoto letmého rozdělení je zřejmé, že podle toho, v jakém prostředí se sociolog medicíny a zdravotnictví pohybuje, je determinováno zaměření jeho činnosti a způsob jeho práce.

V návaznosti na tyto zásadní příspěvky se boư̌livě rozvíjela vědecká a výzkumná činnost v několika klíčových oblastech. Pozornost byla soustředěna především na sociokulturní aspekty zdraví a nemoci pozorované jak na individuální tak na kolektivní úrovni. Obzvlášt byly studovány procesy psychických onemocnění, laické pojetí zdraví a nemoci v kulturním kontextu a otázka sociálně produkovaných rozdílů ve zdravotním stavu populace. Dalšími nosnými tématy se stala problematika stárnutí, umírání a smrti, lékařské profese a zdravotnictví jako instituce.

Mezi klasické práce zabývající se sociokulturní interpretací zdraví a nemoci patří články M. Zborowského [Zborowski 1952] a I. K. Zoly [Zola 1966]. Zborowski sledoval reakce sedmaosmdesáti neurologických pacientů pocházejících ze čtyř etnickokulturních prostředí: židovského, italského, irského a z prostředí amerických starousedlíků. Dokázal, že reakce na bolest, chování v situaci nemocného a požadavky kladené na lékaře jsou výrazně podmíněny skupinovou příslušností nemocného. Tím se stavěl proti tehdejšímu přesvědčení, že práh bolestivosti je víceméně biologickou

\footnotetext{
1 Je obtížné jednoznačně přeložit do češtiny výrazy „sociology in medicine“ a "sociology of medicine“. V současné době neexistuje jasný konsenzus ohledně uživání těchto pojmů. V článku R. G. Petersdorfa a A. R. Feinsteina [PETERSDORF 1981] se objevuje návrh na ještě bohatší strukturaci s využitím mnoha dalších anglických předložek (sociology in, of, for, from, at, around medicine).
} 
normou, standardní pro všechny nezávisle na pohlaví, věku, etnicitě apod. Došel $\mathrm{k}$ závěrům, že podobné reakce na nemoc, pozorované u př́slušníků různých etnicko-kulturních skupin, nemusejí odrážet stejné postoje vůči bolesti, nýbrž že mohou mít $v$ různých kulturách odlišné funkce a mohou sloužit odlišným účelům.

I. K. Zola navázal na Parsonsovu myšlenku, že role nemocného je rolí sociální. Zpochybnil ale, že existuje jednotný kulturní model takového chování, a naopak dokázal, že vnímání obdobných tělesných symptomů je odlišně interpretováno podle etnické př́slušnosti a že tato odlišná interpretace vede $\mathrm{k}$ rozdílnému chování v nemoci. Ukázal, že cesta od tělesného symptomu $\mathrm{k}$ vyhledání odborné péče je plná selektivních krokủ a laického rozhodování, do něhož se promítaji skupinové stereotypy. Na srovnání pacientů italského a irského pủvodu dokumentoval vliv náboženských a kulturních hodnot. Zatímco Italové inklinují k dramatizaci potíži, jež je zvláštním způsobem kulturně reprodukovaného obranného mechanismu tohoto etnika, Irové vycházejí z hlubokého přesvědčení, že život sám je strastiplný a plný odřikání. Toto internalizované zjištění již považují za natolik samozřejmé a všeobecně sdílené, že je nepotřebují vnějškovým způsobem oznamovat ostatním a za kulturně přjjatelné považují sebeovládání a statečné potlačení projevů bolesti a nepohody. Podle Zoly je pro Iry typické, že „chování v nemoci je vztaženo k ideologii hříchu a viny. ... Tři způsoby lokalizace potíží do oblasti očí, uši a úst [pozorované častěji než u Italů, pozn. aut.] mohou symbolicky reflektovat bezprostřední zdroj hříchu něco, co neměli vidět, říci nebo slyšet“" [Zola 1966: 628]. Zola tak nejen vystoupil proti představě, že nemoc je podobně se projevující odchylkou od jednotné normy, nýbrž uvedl vnímání tělesných potiží do relace se spotřebou zdravotní péče a upozornil na dva prípady diskrepance mezi objektivní, klinickou potřebou a skutečnou spotřebou služeb, kde na jedné straně je nekrytá potřeba a na straně druhé nadbytečná spotřeba.

V oblasti sledování zdravotních potřeb populace nelze nezmínit průkopnickou práci E. L. Koose The Health of Regionville [Koos 1954], v níž se zaměřil na to, jakým způsobem obyvatelé jedné geograficky vymezené oblasti definují své zdravotní potřeby a jak na ně reagují. Zjistil, že reakce na zdravotní potíže jsou ovlivněny sociálnětř̀idní pozicí a že chudí občané méně často vyhledávají zdravotní péči při existenci podobných symptomủ. Tento závěr je nepochybně podmíněn zvláštní situací amerického zdravotnictví v 50. letech a neexistencí univerzálního přístupu ke zdravotní péči na bázi potřeb. Avšak i v Evropě, kde odpadají finanční bariéry při čerpání péče, platí, že struktura spotřebované péče je odlišná podle př́slušnosti k sociální vrstvě, i když rozdíly se spíše předpokládají u nejnovějších a nejnákladnějších forem péče. Studiem sociálních aspektů spotřeby služeb se otevírá problematika kulturně podmíněných a produkovaných nerovností a nespravedlností v péči o zdraví.

Dalším klíčovým tématem sociologie medicíny se stala problematika lékařské profese - motivace pro výkon povolání, role lékaře a identifikace s profesí. $\mathrm{V}$ publikaci R. Mertona The Student-Physician [Merton 1957] věnované problematice profesní socializace medikủ zaznělo, že její součástí je vedle předávání př́rodovědných poznatkủ a nácviku klinických dovedností rovněž příprava na výkon profese lékaře v oblasti emocionální a mravní. Být lékařem podle Mertona neznamená pouze složit zkoušky $\mathrm{v}$ teoretických a klinických předmětech, a tedy obstát $\mathrm{v}$ kognitivních nárocích, nýbrž zahrnuje rovněž nácvik postojů, prožívání a chování. V rámci socializace dochází 
i k přípravě na profesní nejistotu a její zvládání. Podle Renée Foxové, která se tomuto tématu v návaznosti na klíčové myšlenky formulované již Parsonsem věnovala i v dalších pracích [Fox 1957, 1980], je lékařská profese charakterizována určitou nevyhnutelnou mírou nejistoty a studenti se učí, jak s touto nejistotou pracovat a jak ji kulturně zvládat. Míra nejistoty je definována objektivními (obecný stav vědění) a subjektivními faktory (vlastní limity) a obtížným rozlišováním mezi nimi. Howard Becker se v publikaci The Boys in White [Becker 1961] zabýval studentskou subkulturou. Hodnotovou orientaci studentů medicíny označil jako pragmatický idealismus. Ačkoliv se $\mathrm{z}$ pohledu vnějšího pozorovatele může zdát, že $\mathrm{v}$ průběhu studia na lékařské fakultě studenti inklinují k cynickým postojům, podle Beckera medici neztrácejí chut pomáhat druhým, ale jejich profesní obranou je snížení citlivosti vůči traumatizujícím skutečnostem a vyrovnání se s nimi formou distance.

Z období 70. let pocházejí studie lékařské profese Eliota Freidsona [Freidson 1970], který se dlouhodobě zabýval profesní mentalitou a kulturou lékařů. Za klíčovou charakteristiku považoval autonomii, v níž rozlišil dvě složky - korporativní (stavovskou) a klinickou (odborně-medicínskou). Korporativní autonomie podle Freidsona znamená, že lékaři mají významný politický vliv na rozhodování o tom, v jakých podmínkách a za jakých podmínek pracují, jak jsou odměňováni, jaké jsou podmínky vstupu do profese (pregraduální i postgraduální vzdělávání) a jak je výkon profese kontrolován. Klinická autonomie vyjadřuje, že výkon profese je natolik diktován odbornou problematikou, že jej nemúže posoudit nikdo, kdo nepřísluší do skupiny lékařủ. Klinickou autonomii si tedy uchovali i lékaři v socialistickém zdravotnictví a z dnešního pohledu byla tato „nedotknutelnost“ jedním $z$ největších privilegií. Důraz na nepřekročitelnost hranic mezi laickým a expertním světem je posilována užíváním odborného jazyka, přístrojů a pomůcek, oblečením a dalšími symboly. Lékařská profese si podle Freidsona svou autonomii vyzískala výměnou za příslib, že bude plnit společensky důležité cíle v souladu s uznávanými hodnotami [Freidson 1970: 82]. Představy lékařủ o sobě samých se však postupně mohou dostávat do kolize s měnícími se požadavky a očekáváními veřejnosti. Proto Freidson na rozdíl od Parsonse nezdůrazňuje univerzalismus, nýbrž hovoři o partikulárních zájmech lékařské komunity a rigidnosti vůči změně [Freidson 1970: 170].

\section{VLIV JINÝCH DISCIPLÍN NA SOCIOLOGII MEDICÍNY A ZDRAVOTNICTVÍ}

Některé z velkých témat, jež byly pro sociologii mediciny mimořádně inspirativní a staly se klíčovými mezníky jejího dalšího rozvoje, byly artikulovány mimo ni. $\mathrm{V}$ tomto článku zmíním jen dva příspěvky. Mezi nejzajímavější a nejpodnětnější patří sociální filozof a teolog Ivan Illich se svou publikací Medical Nemesis [Illich 1976], kde moderní medicínu alegoricky přirovnává $\mathrm{k}$ řecké bohyni pomsty. $\mathrm{V}$ této své knize i dalších článcích formuloval myšlenku, že moderní zdravotnický systém se stal hlavním ohrožením lidského zdraví. Medicína produkuje nechtěné efekty nejen v podobě iatrogenních onemocnění, ale vede také $\mathrm{k}$ sociální a kulturní iatrogenezi v tom smyslu, že moderní lidé ztrácejí schopnost a ochotu vnímat impulzy svého organismu 
a autonomně na ně reagovat. Odevzdávají veškerou odpovědnost lékařủm jako depersonalizovaným a technickým expertům. Sami přijímají mechanický a redukcionistický koncept těla a zdraví. Pasivita a závislost $\mathrm{v}$ oblasti péče o zdraví vede $\mathrm{k}$ neschopnosti být zdravým a $\mathrm{k}$ trvalé odkázanosti na institucionalizovaný systém pomoci. Pro moderní společnost po 2 . světové válce je tak charakteristický rychlý proces medicinalizace $^{2}$ života, který se projevuje $\mathrm{v}$ expanzi medicínských poznatků a dovedností i na řešení problémů, jež svou povahou nejsou nemocí (tedy patologickým stavem) v pravém slova smyslu. Kontrola přirozených sociálních procesů (majících též zdravotní aspekty), jako je lidská reprodukce, stárnutí a umírání, péče o postižené, se tak stává nejen nákladnou, ale také odlidštěnou sférou. Moderní lidé si podle Illiche odvykli řešit své životní problémy a namísto nich utlumuji signály svého těla farmakologickými produkty všeho druhu. Nechtěné efekty jsou pomstou přírody za to, že și lidé přisvojili božské atributy a rozhodují o životě a smrti prostřednictvím technologických manipulací s tělem.

I když některé z Illichových tezí jsou v rozporu se skutečností, která dokladuje výrazné zlepšení parametrů zdraví populace $\mathrm{v}$ důsledku zdravotnických opatření v péči o těhotné a rodičky stejně jako dokazuje prodlužující se střední délku života, jeho provokativní myšlenky obsahují velké poučení a upozorňují na rizika příliš jednostranně zaměřeného a nekritického rozvoje medicíny směrem k ekonomicky neúnosně nákladnému, trvale neudržitelnému a lidským potřebám vzdálenému zdravotnictví. Je velice pravděpodobné, že vzestup zájmu o nekonvenční (alternativní) medicínu v západním světě v posledních dekádách minulého století odráží technologizaci a komputerizaci medicíny a jako by byl nejpřesvědčivějším dủkazem platnosti Illichových kritických názorů, nebot devízou alternativní medicíny je právě apel na nepostradatelnou aktivní úlohu nemocného v procesu léčby a na jeho motivaci ke zdraví, bez níž léčba nemůže být úspěšná.

Dalším autorem, jehož myšlenky jsou v sociologii medicíny rozpracovávány a aplikovány, je Michel Foucault, který interpretuje zdraví v duchu svého pojetí společenské kontroly v moderní společnosti. Moderní přírodovědně založenou a byrokraticky organizovanou medicínu chápe jako formu disciplinární moci nad jedincem. Společnost 19. a 20. století se stává posedlou zdravím a rozvijí „kult zdraví“, kde nechovat se zdravě má eticky negativní konotace. Záplavy doporučení k otázkám zdravého životního stylu vedou nejen $\mathrm{k}$ další medicinalizaci všedního života, ale také $\mathrm{k}$ rozvoji prosperujícího trhu se zdravím, zdravotnickými produkty a službami. Pojem „biomoci“ tak vyjadřuje nové formy výkonu společenské kontroly a „ř́a, kdy lidé v západním světě jsou zdraví, zabezpečení a produktivní“ [Parusniková 2000: 133]. Cena, kterou musejí za své bezpeči zaplatit, je však ztráta autonomie, nebot občané jsou těmito systémy jistot zároveň kontrolováni. Podle Foucaulta je hodnota zdraví obecným ideá-

\footnotetext{
${ }^{2}$ Termín medicinalizace pochází z anglického výrazu „medicalization“. Bývá u nás překládán jako „medikalizace“. Po diskusi na Ústavu lékařské etiky jsme počátkem 90. let přistoupili k uživání termínu medicinalizace, jež podle našeho názoru v souladu s původním anglickým výrazem lépe vyjadřuje věcnou podstatu, a sice přenášení lékařských znalostí a vědomostí do širokých oblastí všedního života. Dáváme tomuto termínu přednost před někdy uváděným „,medikalizace“, nebot toto slovo je v češtině jazykově asociováno s uživáním lékủ a nevhodně omezuje obsah pủvodního anglického výrazu, kde základem bylo adjektivum (medical).
} 
lem a konečným cílem a vede $\mathrm{k}$ tomu, že být zdravým se stává společenským imperativem. Očekává se, že zdraví včetně jeho pěstování je ,synonymem civilizovanosti, úspěšnosti, normality, morality, krásy, síly atd." [Parusniková 2000: 139]. I když se Foucault zabýval spíše historickou analýzou vzniku moderního zdravotnictví po občanských revolucích v období 18. a 19. století a své studie zaměroval zejména na problematiku psychiatrických onemocnění [Foucault 2000], jsou mnohé z jeho myšlenek aplikovatelné i v kontextu medicíny 21 . století, jejímž dominantním znakem je technologizace a využití těla jako objektu expertních intervencí. Pro sociology z jeho odkazu dále vyplývá, že zdraví je novou formou společenské diferenciace a nerovnosti a zdravotnictví novou podobou méně viditelného, rafinovaného společenského dohledu. ${ }^{3}$

Sama myšlenka, že medicína je institucí sociální kontroly, však nemusela být do sociologie zanášena zvenčí a $v$ mnoha případech je obtížné rozhodnout o prvenství některého $\mathrm{z}$ autorů. Explicitně se objevuje vlastně již v kapitole $T$. Parsonse, dále je obsažena v pracích Ervinga Goffmana [Goffman 1961] a I. K. Zoly [Zola 1970]. Podle Zoly se medicína stává „pramenem pravdy“ a dominantním nástrojem sociální kontroly vytlačujícím tradiční instituce náboženství a práva. Rozlišování mezi „zdravím“ a ,nemocí“ se stává relevantním ve stále širších oblastech společenského života. Medicinalizace se podle Zoly netýká pouze psychiatrie, jak se původně soudilo, nýbrž jejím podhoubím je složitý a byrokratický systém spočívající na stále větší důvěře v expertní vědění a jeho legitimitu. Komputerizace anamnestických informací povede ke „Zveřejňováni "stále širších oblastí intimního života. Podle Zolova názoru, vysloveného již v r. 1972, ,s příchodem počítačů dochází ke ztrátě soukromí, nebot zatímco pamět lékaře, která až dosud byla hlavním místem zpracování informací, má lidské limity, pamět počítače je přenosná a téměř nevyčerpatelná“ [Zola 1970: 493]. Medicína si navíc podržuje výsadní právo zkoumat tabuizované problémy - vnitřní procesy těla a mysli, a stává se privilegovaným nástrojem legitimního výkonu veřejné moci nad jedincem, který je „prohlášený“ za nemocného.

Zrod sociologie medicíny a zdravotnictví spadá do období americké poválečné hospodářské prosperity, charakterizovaného prudkým rozvojem vědy a techniky a př́edevším optimistickou vírou v pokrok bez otřesủ a konfliktů. Nikdy nebyla a asi již ani nebude důvěra $v$ možnosti vědy a techniky tak hluboká a bezhraniční jako v této epoše „zázračných úspěchů“. V tomto smyslu byla kultura světa na obou stranách železné opony stejná, orientovala se na hospodářský růst a pěstování kultu vědy a techniky jako hlavního atributu moderní kultury. Rychlá aplikace vědeckotechnologických poznatků $\mathrm{v}$ oblasti zdravotnictví vedla $\mathrm{k}$ tomu, že se medicína stala jedním $\mathrm{z}$ klíčových symbolů úspěchů moderní společnosti, nebot tyto poznatky využívala pro dosahování důležitých etických hodnot a ideálů. Úkolem aplikované sociologie tak v prvních letech po jejím vzniku bylo obhajovat společenskou funkci medicíny, přispívat $k$ šiření jejího pozitivního image, a tak napomáhat jejímu snazšímu fungování. Podle amerických teoretiků tedy charakter sociologie medicíny byl na počátku jejího vzniku spíše konzervativní. Ke změně došlo až v 60 . letech, kdy začala být instituce moderní medicíny před-

\footnotetext{
${ }^{3}$ Dalším filozofem, který se výslovně zabývá problematikou zdraví, je HANS-GEORG GADAMER ve své knize The Enigma of Health.
} 
staviteli kritického hnutí napadána jako součást establishmentu industriální a konzumní společnosti. V této souvislosti můžeme chápat zde zmiňované názory „heretických“ autorů kritické generace, jako je např. Illich, Freidson, Dubos, Maxmen, Goffman, Zola, McKeown, a rozumět posunu od parsonsovského paradigmatu.

\section{VYUŽITÍ METODOLOGICKÝCH PŘÍSTUPŮ V SOCIOLOGII MEDICÍNY A ZDRAVOTNICTVÍ}

Sociologie medicíny je oblastí, v níž jsou paralelně využívány kvantitativní i kvalitativní přístupy. Protože se jedná o především aplikovanou disciplínu, rozhoduje o volbě té které metody povaha zkoumaného problému a ne principiální stanovisko výzkumníka. Spor o metodu tedy rozhodně nenabývá té razantnosti, jakou nalezneme v akademickém sociologickém prostředí. Dủležité je rozlišovat, na jaké rovině studia problému se pohybujeme - zda spíše na individuální či mikrosociální úrovni nebo zda studujeme velké populační skupiny či strukturální problémy. Podle povahy problému a jeho empirické „dostupnosti“ pak je vybírána metoda a technika výzkumu. V rámci sociálního lékařství, veřejného zdravotnictví a sociální epidemiologie se často pracuje s rozsáhlými vzorky populace, takže data $\mathrm{z}$ těchto souborů vyžadují rutinní statistické zpracování a leckdy dovolují i složité statistické procedury, jako např. modelování. V oblasti ošetřovatelství či lékařské etiky se však ukazuje, že mnohé problémy (umírání, handicap, komunikace, dlouhodobá péče, technologie) jsou př́stupné pouze alternativně - prostřednictvím kvalitativních metod. Byl to tedy především vlastní charakter mnoha zdravotně-sociálních problémů, jenž si vyžádal metodologické inovace. Mnoho výzkumů profilujících se jako kvalitativní se realizovalo právě ve zdravotnickém prostředí [Glaser 1965, 1968] [Goffman 1961]. Oblíbené jsou obzvláště postupy skupinových rozhovoru (focus groups), protože povaha řešení mnoha zdravotně-sociálních či etických problémů je konsenzuální. Řešení nespočívá v expertním posouzení, ale ve vyjednávání aktérů a hledání dohody. Žádný odborník nemůže např. vypracovat závazný model komunikace lékař-pacient, nebot komunikace se odviji podle momentální situace a potřeb přímých účastníků, nikoli odborníků. Mapování těchto názorů a potřeb, vztahujících se často $\mathrm{k}$ otázkám intimního a privátního charakteru, pak vede $\mathrm{k}$ preferenci kvalitativních postupů, jejichž výsledkem je spíše pojmenování problému, jeho nová artikulace při zohlednění různých perspektiv a relevancí. Jako mimořádně užitečné se ukazuje propojování kvantitativních a kvalitativních přístupů formou triangulace, jak ji obhajuje např. Denzin. Kvalitativní sondy, at již ve fázi přípravy výzkumu nebo jako paralelně probíhající a doplňující výzkumné výsledky, pomáhají oveř̌ovat správnost a spolehlivost našeho úsudku a obohacovat celkový obraz problému. Např. skupinová diskuse s lékaři zabývajícími se nekonvenční medicínou postavila problematiku sporu vědecké a alternativní medicíny do nového kontextu charakterizovaného mocenským konfliktem a obhajobou skupinových ekonomických a politických zájmů.

Užití kvalitativních technik však rozhodně není jednodušší ani pohodlnější variantou výzkumu, nebot staví výzkumníka před nové technické problémy a etickou odpovědnost. Pokud sociolog hovoří s pacienty, musí citlivě hlídat hranice, aby se rozho- 
vor s nemocným nestal psychoterapeutickým rozhovorem, pro který není kvalifikován a který není ani účelem setkání. Sociolog v kvalitativním zdravotnickém výzkumu musí balancovat mezi tím, aby neomezoval hovořící osobu, a současně nesmí dopustit, aby se klient tím, že hovoři o zdravotně relevantních otázkách dotýkajících se často soukromých sfér, nedostal do psychické krize, v níž mu sociolog nemůže pomoci. Důležitou otázkou je anonymizace dat, obzvlášt v těch př́padech, kdy jsou probírána intimní či jinak choulostivá témata (nelze zapomenout, že pro pacienta je vždy důležitější ošetřující lékař než výzkumník). Pokud jsou partnery v rozhovoru lékaři, musí sociolog své výzkumné představy přizpůsobit jejich časovým možnostem stejně jako tomu, že relevanci témat si určují většinou sami. Realizovat opakované otevřené hloubkové rozhovory a vracet se $\mathrm{k}$ partnerům rozhovoru podle potřeb výzkumníka je spíše přáním než skutečností. Ve všech případech zahrnuje problematika zdraví a nemoci přirozeně klinické aspekty a klade nároky na odbornou přípravu sociologa, aby se seznámil alespoň se základními medicínskými pojmy.

I když v lékařském prostředí je nadále upřednostněn spíše kvantitativní př́stup jako legitimní způsob vědeckého poznávání a není snadné před lékaři obhájit výzkum spočívající pouze na výpovědích několika účastníků, byt hloubkových, autentických a detailně obsahově analyzovaných, kvalitativní metody si získávají stále větší renomé, protože se výborně empiricky osvědčily při zkoumání problémů zcela nezvládnutelných tradičními sociologickými technikami. Stává se také stále častěji, že i ve zdravotnickém výzkumu narážime na rostoucí „únavu“ respondentů z dotazníků a na klesající ochotu populace participovat na výzkumech, což se projevuje nízkou návratností dotazníkủ nebo vysokou mírou odmítnutí rozhovoru. Obě tyto okolnosti mohou výrazně prodražit realizační náklady na výzkum a zpochybnit reprezentativnost výsledků. I z těchto důvodů je nutno zvažovat efektivitu použití té které metody.

\section{NA JAKÉ TEORII MƯŽE SOCIOLOGIE MEDICÍNY STAVĚT?}

Vlastní teoretické zázemí sociologie medicíny je chudé. Pokud pracuje na teoretické úrovni, přenáší nejčastěji obecné sociologické teorie do medicínského kontextu. Vzhledem ke zcela klíčovému charakteru pojmu solidarita v organizování a financování všech evropských zdravotnických systémů, který se však tváří v tvář reálným demografickým a jiným procesủm dostává do vážné krize, může být inspirativní např. Durkheimovo pojednání o organické a mechanické solidaritě nebo Tönniesova dichotomie pospolitosti a společnosti. Z vlastní teorie sociologie medicíny je možné kromě Parsonse připomenout příspěvek Ervinga Goffmana a jeho teorii totálních institucí.

Ne všichni sociologové v oblasti medicíny explicitně deklarují své teoretické pozice. Podle P. Aldersonové [Alderson 1998: 1007] je ale teoretické východisko přítomno vždy a ovlivňuje, jakým způsobem je formulována výzkumná otázka, jak jsou data sbírána a jak jsou interpretována. Zủstává-li teoretický předpoklad nereflektován, působí skrytě a může vést $\mathrm{k}$ zamlžování a nesprávné interpretaci získaných výsledků. Nejrozšířenějším teoretickým východiskem empirické sociologie medicíny byl pozitivismus. Sociologie medicíny se etablovala v době, kdy právě tento př́istup ve vědě a v sociologii kulminoval. Sociologické postupy uplatňované ve výzkumech zdravot- 
ního stavu a zdravotního chování na velkých skupinách populace vycházejí právě $\mathrm{z}$ presumpce parcializace a měřitelnosti reálných jevů a $\mathrm{z}$ př̀edpokladu distance mezi výzkumníkem a objektem výzkumu. Vnější kontext, v němž byla sociologie medicíny aplikována, ji vedl $\mathrm{k}$ tomu, že se snažila vnímat sociálně-zdravotní problematiku $\mathrm{v}$ termínech fyzikálních a klinických a měřit ji podle pravidel binární logiky. Sociologie medicíny tak v době svého vzniku do značné míry rezignovala na reflektování významu lidského jednání a ztratila schopnost vnímat ambivalentní charakter mnoha fenoménů spojených se zdravím a nemocí. Ve snaze získat si prestiž a uznání v ,exaktním“" světě biomedicíny se přizpủsobila paradigmatu přírodních věd (viz úvodní citát R. Strause). K dosažení zamýšleného cíle, jímž mělo být zrovnoprávnění sociologie při studiu zdravotnických problémů, tato strategie však stejně nevedla.

Dobově poplatný byl rovněž Parsonsův teoretický příspěvek z 50. let, nahlížející společnost jako jednotný celek, který je orientován na plnění společenských funkcí a úkolů. Strukturálně-funkcionální východiska byla zpochybněna autory nastupující generace vycházející z pozic kritické sociologie a teorie konfliktu. Tak jako celá společnost i medicína je oblastí střetávání různých zájmů a mocenského soupeření a konfliktů. Lékaři jako reprezentanti sociální kontroly určují, kdo je oprávněn užívat sociálních výhod vyplývajících ze statutu nemocného. Mezi světem expertů a laickým světem je nepřekonatelná oblast, přičemž vědění je nástrojem moci, jež je posilována byrokratizací zdravotnictví. Eliot Freidson, který z těchto pozic analyzoval společenské postavení a roli lékaře, vycházel z konfliktu mezi zájmy lékařŭ a pacientů a z malé ochoty lékařu reagovat na měnící se společenské požadavky. Medicína jako jeden $z$ důležitých a reprezentativních společenských segmentů disponuje obrovskou společenskou autoritou určovat všeobecně závazná pravidla hodnocení zdravotnických problémů ${ }^{4}$. Podle G. Benneta ${ }^{5}$ [Bennet 1987: 167] pronikají aspekty moci všemi oblastmi činnosti lékaře, lékařská role je především rolí mocenskou. V krajní podobě se někdy setkáváme $s$ tendencí $\mathrm{k}$ omnipotenci, přenášení expertního statusu a rozhodovacích kompetencí mimo vlastní odbornost a prosazování medicínských př́stupů jako dominantních i při posuzování problematiky sociálního či politického charakteru.

$\mathrm{Z}$ mnoha důvodů je možno považovat moderní medicínu $\mathrm{v}$ duchu Luhmannových slov za př́kladný autopoietický systém, sebereferenční a seberegulující sociální instituci s pevnými hranicemi vymezujícími její prostředí vůči ostatním subsystémům [Šubrt 2001: 124-125]. Není to jen proto, že si medicína stanovuje pro sebe závazné normy a pravidla chování, nýbrž je to také pro onu rigidnost a uzavřenost vůči vnějšíi-

\footnotetext{
${ }^{4}$ Při projednávání problematiky postgraduálního vzdělávání lékařủ na půdě parlamentu v r. 2001 došlo $\mathrm{k}$ ostrému sporu mezi reprezentanty lékařů na straně jedné a ministerstvem zdravotnictví s Institutem postgraduálního vzdělávání ve zdravotnictví na straně druhé. Ač byla na přetřesu zdánlivě odborná problematika pravidel a norem dalšího vzdělávání lékařủ, jádrem konfliktu, charakterizovaného mnoha emocionálními výpady ze strany lékařŭ, byl spor o autonomii lékařské profese mezi lékaři a státem, a tedy otázka, jaká pravidla budou platit pro postgraduální vzdělávání a kdo je smí určovat. Článek o devitalizaci autora Dvơ̌ćčka [DvoŘÁCEK 2002] končí větami: ,Je možné připustit, aby si laici osobovali právo zasahovat do práce a kompetencí odborníkủ a zpochybňovali zákonná pravidila a normy? Mủže nám to být opravdu jedno?"

${ }^{5}$ Zde se Bennet v linii nietzschovsko-foucaultovského myšlení nepochỵbně hlásí $k$ myšlence, že ,poznání a věda nejsou samy o sobě cílem lidského usilování, nýbrž slouží moci““[ŠU
} 
mu prostředí. Objevuje se názor, že medicína tím, co umí a dělá, je nejprogresivnějším nositelem postmoderních změn, současně je ale poslední, kdo je ochoten tuto skutečnost uznat a nadále trvá na principech moderny [Hodgkin 1996:1568]. Autopoiesis medicíny a zdravotnictví vyplývá $\mathrm{z}$ autonomie, již lékaři v procesu profesionalizace medicíny od společnosti získali. Tato autonomie rozhodovat o klíčových podmínkách a pravidlech fungování a reprodukce systému medicíny, jež je jedním $z$ definičních znaků profese, je ale podle Freidsona společností pouze zapůjčena na oplátku za to, že profese, jež tohoto privilegia (autonomie) požívá, bude orientovaná na uspokojování společenských cílů a veřejného zájmu. Image této servisní či kolektivní orientace je tedy nezbytné pro to, aby společnost uznala a nadále respektovala právo lékařské profese na seberegulaci a uzavřenost vůči laickému prostředí. Primárním cílem medicíny jakožto instituce tedy není uspokojovat ekonomické, vědecké či jiné zájmy profesionálů v ní působících, nýbrž plnit společenské úkoly související s péčí o zdraví na individuální i kolektivní úrovni. Neznamená to sice, že každý lékař je nutně větším altruistou než jiní profesionálové. Je tím však řečeno, že orientace na skupinové cíle je „veřejnou etiketou“ této profese a je sociálním závazkem za udělení autonomního postavení. Společnost se sice snaží tváři $\mathrm{v}$ tvář změněným sociálním požadavkủm vyvijet tlak na větši transparentnost a otevřenost (accountability) lékařského výkonu, lékaři jej však nepovažují za vhodný či realistický, někdy jej vnímají jako „šikanu“. $\mathrm{Na}$ druhé straně se $\mathrm{v}$ debatě $\mathrm{k}$ podpoře dalšího výzkumu (a s tím spjatých investic) anebo naopak $\mathrm{k}$ udržení statu quo (proti inovacím) tak často argumentuje hodnotou zachráněných lidských životů a službou lidstvu.

Medicína je nejen „distributorem dobra“, nýbrž představuje v soudobém světě také důležitý a poměrně rozsáhlý trh svého druhu, na který se napojuje celá řada producentů výrobků a služeb. ${ }^{6}$ Ti se prostřednictvím lékařủ snaží uspokojovat své ekonomické zájmy. Nad vyrovnaným poměrem sil jednotlivých skupin aktérů musí bdít koncepčně rozvíjená zdravotní politika státu, reprezentující zájem celospolečenský a dlouhodobý. Podle kritických autorů a v duchu Foucaultových slov pak ,je prvním úkolem lékaře politická akce, boj proti nemocem musí začínat bojem proti špatné vládě“ [Foucault 2000: 33]. Z pozic zastánců teorie konfliktu rovněž vychází (zatím stále neúspěšný) apel na reformu amerického zdravotnického systému a na to, aby se dostalo pozornosti otázkám spravedlnosti. V jiné situaci se nachází evropský výzkum zdravotních nerovností, který nemusí být nesen snahou reformovat stávající systém, nebot právo na zdravotní péči je uznáno jako právo občanské. Ten je veden převážně $\mathrm{v}$ pozitivistickém duchu a je charakterizován snahou o exaktní měření rozdílů $\mathrm{v}$ indikátorech zdravotního stavu a životního způsobu na velkých skupinách populace stejně jako úsilím formulovat univerzální trajektorii determinujících vlivů.

V 60. letech se vedle kritické teorie začal v sociologii medicíny paralelně uplatňovat symbolický interakcionismus a sociálněkonstruktivistický př́stup. Problematika psychických onemocnění a psychiatrických zařízení byla atraktivní půdou pro studium procesů konstruování pojmu nemoci, pacientovy kariéry a společenské reakce na

\footnotetext{
${ }^{6}$ Roční náklady českého zdravotnictví činí kolem 140 mld Kč. Ve vyspělých zemích spotřebuje zdravotnictví mezi 7-14\% hrubého domácího produktu.
} 
odchylné chování. Obecné závěry, jež E. Goffman na základě studia psychiatrické nemocnice sumarizoval ve své teorii totálních institucí, mohly být vztaženy nejen na nezdravotnické instituce, ale v jisté míře i na všeobecné nemocnice všech typů a úrovní a na další sociálně-zdravotní instituce. Strauss a Corbinová [Corbin 1988; Corbin 1991] rovněž ověřovali nosnost konstruktivistických př́stupů na problematice vnímání těla, se zvláštní pozorností věnovanou tělesnému a mentálnímu handicapu. Také hermeneutická sociologie může navázat na tyto tradice především důrazem, který klade na vzájemnost zkoumajícího a zkoumaného, a zproblematizováním pojmu pravda. Pochopení, že aktéři vztahů se pohybují ve vlastních perspektivách a prirozených světech, nám může pomoci porozumět mnoha situacím, $k$ nimž ve zdravotnictví dochází, obzvláště ve vztahu mezi lékařem a pacientem. Múže posloužit při formulaci etických norem, např. pro oblast komunikace mezi lékařem a nemocným či pro formulaci práv pacientů. I odborněmedicínský diagnostický proces je vědeckou a sociální konstrukcí a jeho výsledek závisí na tom, jaké otázky si lékař klade a co hledá, a především na tom, jaký je on sám. Sociální konstruktivismus a všechny další př́istupy vycházející z fenomenologické filozofie a sociologie tak upozorňují na to, že svět medicíny je také světem sociálních interakcí, významů, jazyka a symboliky.

\section{JAKOU IDENTITU MÁ SOCIOLOG MEDICÍNY A ZDRAVOTNICTVÍ, KOHO REPREZENTUJE A PRO KOHO VLASTNĚ PRACUJE?}

Podob sociologie medicíny a zdravotnictví je mnoho. V duchu Strausova příměru sociologa medicíny $\mathrm{k}$ chameleónovi záleží na zadání a kontextu, v němž pracuje. Sociolog se tak dostává do určitých problémů vždy, at již setrvává na půdě sociologické disciplíny nebo pracuje přímo v aplikované oblasti. Proto také někteři autoři hovoří o krizi identity sociologie medicíny. Pokud se sociolog pohybuje na lékařských fakultách a zdravotnických zařízeních, je limitován nejen úkolem tam artikulovaným, ale také hodnotami a normami tohoto prostředí. $\mathrm{V}$ oblasti sociology in medicine nemůže práce sociologa postrádat zdravotnickou smysluplnost a sociolog se nemůže zabývat pouze tím, co ho teoreticky zajímá, nebot to může být pro zdravotníky snadno zcela irelevantní nebo banální. Často ani svou práci nemůže nazývat explicitně sociologickou, nebot participuje $\mathrm{v}$ rámci jiné disciplíny - sociální epidemiologie, sociálního lékařství, sociální pediatrie, sociální psychiatrie, zdravotní politiky, lékařské etiky či veřejného zdravotnictví. $V$ aplikované oblasti je sociolog vždy vázán zdravotnickou zakázkou, tedy tím, že závažnost problematiky, klíčovou otázku a hypotézy většinou definuje zdravotnický odborník a ne sociolog. Výhodou však je přímé praktické využití výsledků výzkumu a pocit spoluúčasti na užitečném díle. Prezentace výsledkủ aplikovaného výzkumu stejně jako snaha uplatnit sociologii ve vzdělání mediků však většinou znamená ochuzení sociologické terminologie a zredukování jazyka i složitosti náhledu v zájmu usnadnění interdisciplinární komunikace. Rozvíjet sociologicky zajímavá témata a vyjadřovat je v sociologických kategoriích a sociologické perspektivě je tak spíše možné v oblasti sociology of medicine. Zde však sociologovi hrozí jiné riziko, to, že se soustředí na momenty, které mimo hranice této disciplíny nebudou považovány ani za důležité, ani za zajímavé. Pokud se mu nepodaří 
přesvědčit zdravotníky o výzkumu a získat je alespoň pro pasivní spolupráci, mohou mu důležité informační zdroje zůstat nepřistupné a vstup do terénu odepřen.

I když sociologa na poli medicíny a zdravotnictví očekávají různé nástrahy, klíčové je, aby tváří v tvář nárokům vnějšího prostředí (a snahy o přežití) neztratil svou kvalifikaci a motivaci pozorovatele sociálních procesů $\mathrm{v}$ jejich komplexnosti a neztotožnil se bezvýhradně s perspektivou zdravotníků. Sociolog ve zdravotnictví nabízí $\mathrm{z}$ pohledu medicíny sice laickou (jakoby méně hodnotnou), ale z pohledu sociálních věd zasvěcenou analýzu složité interdisciplinární problematiky. Jeho optika je jiná, měla by být širší, nesená respektem $\mathrm{k}$ žité skutečnosti, takové, jaká je ve své navrstvenosti a zašifrovanosti. Nezastupitelný (i když ne vždy vítaný) je sociolog právě proto, že prosazuje laickou perspektivu jako plně legitimní, jež musí být brána v potaz, a že ji obhajuje přes veškeré nesnáze, nepohodlí a komplikace, které vnášení laického pohledu do odborného světa medicíny doprovází. Proto sociolog, který je v duchu slov Alfreda Schütze ,cizincem“ ve světě medicíny, může být vnímavější vůči otázkám, jež si profesionálové ani neuvědomují. Mnohé problémy může artikulovat jako sociální problémy, jež zasluhují veřejné pozornosti, a tím upozornit na jejich existenci. Zde nemám na mysli vytváření umělých (pseudo)problémů, tam kde nejsou, nýbrž detabuizaci skrytých otázek. Právě proto, že relevance sociologicky formulovaných problémů nemusí být shodně vnímána zdravotníky, kteři ale současně dominují v dělbě moci a práce, je pozice sociologa v medicíně a zdravotnictví velice zranitelná. Spolupráce mezi medicínou a sociologií není sice nemožná a mnohé výzkumy dokazují vzájemné obohacování a plodnost takového setkání, je však vždy náročná vzhledem k odlišným paradigmatickým východiskủm, odlišnému jazyku a odlišsnému mocenskému postavení.

\section{Literatura}

ALDERSON, P. 1998. „The importance of theories in health care“. In: Br Med J 317: 1007-110.

BECKER, H. S. - GEER, B. - HUGHES, E. C. - STRAUSS, E. L.1961. The Boys in White. Chicago: The University of Chicago Press.

BENNET, G.1987. The Wound and the Doctor: Healing, Technology and Power in Modern Medicine. London: Martin Secker and Warburg.

BLACKWELL, E.1902. Essays in Medical Sociology. London: Ernest Bell.

CORBIN, J. - STRAUSS, A. 1988. Unending work and care. Managing chronic illness at home. San Francisco, CA: Jossey-Bass.

CORBIN, J. - STRAUSS, A. 1991. „Comeback: Overcoming disability“. In: Albrecht, G., Levy, J. (eds.). Advances in medical sociology. Greenwich, CT: JAI Press, sv. 2.

DVOŘÁČEK. MF Dnes 30. 1. 2002.

FOUCAULT, M. 2000. The Birth of The Clinic. London: Routledge.

FOX, R. 1957. „Training for Uncertainty“, pp. 207-241. In: Merton, R. K., Reader, G. G., Kendall, P. C. The Student-Physician. Cambrige, Massachusetts: Harvard University Press.

- 1980. „The evolution of medical uncertainty“. In: Milbank Memorial Fund Quarterly 58 (1): 1-49.

FREIDSON, E. 1970. Profession of Medicine. New York: Dodd Mead.

GLASER, B. - STRAUSS, A. 1965. Awareness of dying. Chicago: Aldine.

GLASER, B. - STRAUSS, A. 1968. Time for dying. Chicago: Aldine.

GOFFMAN, E. 1961. Asylums. New York: Doubleday Anchor, Garden City.

HODGKIN, P. 1996. „Medicine, postmodernism and the date of certainty“. In: BMJ 313, s. 1568-9. 
ILLICH, I. 1976. Medical Nemesis: The Expropriation of Health. New York: Pantheon Books.

JANECKOVÁ, H. 2001. „Transformation of the Health Care System in the Czech Republic - a sociological perspective“, pp 347-363. In: Cockerham, W. C. (ed.). The Blackwell Companion to Medical Sociology. Oxford/Malden Massachusetts: Blackwell Publ.

KAPR, J. - KOUKOLA, B. 1998. Pacient-revoluce v poskytování péče. Praha: SLON.

KOOS, E. L. 1954. The health of Regionville. New York: Columbia University Press.

KR̆İŽOVÁ, E. 1993. Úvod k sociologii medicíny a zdravotnictví. Praha: Karolinum.

MATCHA, D. A. 2000. Medical Sociology: a comparative perspective. Needham Heights, Massachusetts: Allyn and Bacon.

MERTON, R. K. - READER, G. G. - KENDALL, P. C. 1957. The Student-Physician. Cambrige, Massachusetts: Harvard University Press.

PARSONS, T. 1951. "Social structure and dynamic process: The case of modern medical practice“, pp. 429-479. In: The Social System. New York: The Free Press of Glencoe.

PARUSNIKOVÁ, Z. 2000. „Biomoc a kult zdraví“. Sociologický časopis 36 (2): 131-142.

PETERSDORF, R. G. - FEINSTEIN, A. R. 1981. „An informal appraisal of the current state of medical sociology“. Journal of American Medical Association 245 (9): 943-950.

RUDERMAN, F. A. 1981. „What is medical sociology?“. Journal of American Medical Association 245 (9): 927-929.

STRAUS, R. 1957. „The nature and status of medical sociology“. American Sociological Review 22: 200-204.

ŠUBRT, J. 2001. Postavy a problémy soudobé sociologické teorie. Praha: ISV.

ZBOROWSKI, M. 1952. „Cultural components in responses to pain“. The Journal of Social Issues 8 (4): $16-30$.

ZOLA, I. K. 1966. „Culture and symptoms - an analysis of patients’ presenting complaints“. Amer. Sociol. Review 31: 615-630.

- 1970. „Medicine as an institution of social control“. Sociol. Review 22 (4): 487-504.

\section{Sociology in the Field of Medicine and Healthcare - Stranger or Intruder?}

\section{Summary}

Medical sociology is a discipline that applies sociological perceptions, theoretical approaches and empirical methods to the study of healthcare issues. Modern medicine is one of the key symbols of modern society and its achievements in terms of human intervention in nature. A sociologist studying healthcare issues faces certain specific problems deriving from the socio-cultural framework of modern medicine and the natural sciences in general. By pursuing sociology in medicine he may lose his identity and autonomy, but by pursuing sociology of medicine he may tend to study issues perceived as irrelevant by healthcare experts. Being a "stranger" in the field of medicine may, however, mean that a sociologist can contribute to the articulation of new problems as public matters or social problems. He may also be perceived as a representative of the lay perception of healthcare issues. Both quantitative and qualitative models are used in this field, mostly in a process of triangulation that gives a fuller and more truthful idea of reality from the perspectives of different actors. Although the natural sciences are the basis of medical knowledge and skills, medicine is also a symbolic world with its own culture, values and norms. 